UDK 27-9“01/07“Hieronymus, sanctus 2-558.5(044):27-9“01/07“" https://doi.org/10.31337/oz.75.2.4 Pregledni rad

Primljeno: 22.8.2018. Prihvaćeno: 11.5 .2020$.

\title{
O naravi i stupnjevima zaređenih službenika $u$ pismima sv. Jeronima
}

\author{
Anto Mišić ${ }^{*}$
}

\begin{abstract}
Sažetak
Članak je napisan prigodom 1600. obljetnice smrti sv. Jeronima, velikoga ranokršćanskoga pisca, bibličara i teologa. Jeronim se rodio u Stridonu, gradiću na granici Dalmacije i Panonije, koji su Goti razorili još za njegova života. U članku je prikazan Jeronimov nauk o naravi i stupnjevima zaređenih službenika prema zbirci pisama koja sadržava 154 pisma, od kojih je Jeronim napisao 116, a 16 je pisama upućeno njemu. U zbirku su uključena i pisma od kojih je neka Jeronim preveo na latinski, a neka su apokrifna. Važnost $i$ bogatstvo zbirke pisama očituje se u mnoštvu različitih tema i brojnosti osoba s kojima se Jeronim dopisivao. O zaređenim službenicima Jeronim piše u 27 od 116 autentičnih pisama, ponekad samo u naznakama, a u četiri pisma opširnije raspravlja o svećeništvu. Jeronim koristi tada uobičajeno nazivlje o zaređenim službenicima: episkop, prezbiter i đakon. Vrlo rijetko koristi i latinske nazive sacerdos $i$ sacerdotio, koje primjenjuje isključivo na episkope i prezbitere, ali ne na đakone. Kada želi jednim nazivom ujediniti sve zaređene službenike, koristi naziv clericus. Da bi netko postao službenik u Crkvi, prema Jeronimu, odlučan je izbor i poslanje zajednice, polaganje ruku samo je potvrda poslanja. U svojim pismima Jeronim govori o biti i različitim stupnjevima zaređenih službenika (episkopa i prezbitera), povezujući ih s apostolima, sakramentima i Crkvom. Najvažniju ulogu koju imaju u zajednici slavljenje je sakramenata, napose euharistije. Jeronimova je posebnost da on odlučno niječe bitnu razliku u stupnju svetoga reda između episkopa i prezbitera, razlikuje ih samo služba koju svaki ima u Crkvi. Razlika je, dakle, više sociološka nego ontološka. Đakoni se bitno razlikuju od episkopa i prezbitera, oni su nasljednici sedmorice koje su apostoli izabrali $i$ odredili za služenje u zajednici. Premda Jeronim smatra da ne postoji bitna razlika u svetom redu između episkopa i prezbitera, on ne niječe različitost ulogâ $i$ službi koje obnašaju u Crkvi. Korijeni te različitosti nisu teološki, nego društveni i ustrojbeni. Budući da je Crkva također i ljudska zajednica,
\end{abstract}

* Prof. dr. sc. Anto Mišić, Fakultet za filozofiju i religijske znanosti Sveučilišta u Zagrebu. Adresa: Jordanovac 110, 10000 Zagreb, Hrvatska. E-adresa: amisic@ffrz.hr 
ona mora imati ustroj sličan drugim ljudskim zajednicama, primjerice vojsci ili posadi broda u kojima se sluša zapovjednika.

Ključne riječi: Crkva; episkop; prezbiter; đakon; kler; svećenik; zaređeni službenik; pismo.

\section{Uvod}

Prije 1600 godina umro je sv. Jeronim, prezbiter, veliki ranokršćanski pisac, koji je svojim spisima stoljećima snažno utjecao na mnoge. Posebni ugled i štovanje Jeronim je imao u hrvatskim krajevima, što pokazuju mnoge crkve njemu posvećene, bratovštine i udruge koje nose njegovo ime. Puno je podataka o njegovu životu, a mnogi se nalaze u njegovim spisima. Tako o svojem podrijetlu piše: »Jeronim, rođen od oca Euzebija, u gradu Stridonu, koji je razoren od Gota, a bio je nekad granica Dalmacije i Panonije $\ll .{ }^{1}$ Već se stoljećima ne zna gdje se točno nalazio grad Stridon, u kojem se Jeronim rodio 347. ili 348. godine. ${ }^{2}$ Rodni kraj opisuje kao krševit, a o njegovim stanovnicima vrlo je kritičan: »jedini bog je trbuh i živi se dan za danom; tko je bogatiji smatran je svetijim « (Jeronim, 1996a, 29-30, Ad Chromatium, Iouinum, Eusebium, ep. 7, no. 5). Jeronim je umro u Betlehemu (u Palestini) 30. rujna 419. ili 420. godine.

Zbog ograničenosti okvira jednoga članka nećemo se baviti Jeronimovim životopisom ni brojnošću i tematikom njegovih spisa. Zanimaju nas njegova pisma i što se u njima govori o naravi i stupnjevima zaređenih crkvenih službenika svećenicima i biskupima. O tom se je rijetko pisalo na hrvatskom jeziku, a Jeronim o odnosu svećenika i biskupa ima zanimljivo stajalište. U vrijeme nastanka Jeronimovih pisama, tema o crkvenim službenicima vrlo je prisutna u kršćanskoj literaturi. Spomenimo samo: Apologeticus de fuga Grgura Nazijanskoga, De Sacerdotio Ivana Zlatoustoga, Ambrozijev tekst De officiis minisstrorum, pa do više tekstova sv. Augustina. ${ }^{3}$ Ranokršćanski spisi potvrđuju da su, od početka, u kršćanskim zajednicama postojale različite službe i službenici, premda u 1. stoljeću još nije točno određena njihova uloga ni odgovarajuće nazivlje. Širenjem kršćanstva izvan Palestine i povećanjem broja kršćana, službenici su imali sve važniju ulogu u organizaciji i vođenju kršćanskih zajednica. ${ }^{4}$ Početkom 2 . stoljeća, u pismima sv. Ignacija Antiohijskoga, ministerijalna trijada (biskupi, svećenici

1 »Hieronymus patre Eusebio natus, oppido Stridonis, quod a Gothis eversum, Dalmatiae quondam Pannoniaeque confinium fuit « (Jeronim, 1845, 715-717; cap. CXXXV, br. 953). Citate izvorno napisane na latinskom jeziku preveo je autor članka.

2 Stridon su razorili Goti oko 376. i danas se ne zna gdje se on točno nalazio. Od nekoliko pretpostavki čini se najvjerojatnija ona našega arheologa Frane Bulića (1920), koji smatra da se Stridon nalazio u blizini današnjega Grahova polja.

3 Usp. Pintard i Daniélou, 1960; Gryson, 1968; Boularand, 1971.

4 Postoji opširna literatura o toj temi. Usp. Leonardi, 1977; Schillebeeckx, 1982, 13-89; Greshake, 1982. 
i đakoni) smatrana je vrlo važnom u crkvi. ${ }^{5}$ U 3. stoljeću sve su brojniji tekstovi o crkvenim službenicima, a nazivlje i uloga sve su jasnije određeni. U spisima sv. Ciprijana puno je podataka o crkvenim službenicima u afričkim zajednicama. U Hipolitovu spisu Apostolska tradicija opisan je prvi obred ređenja, te je za sve pripadnike klera (biskupe, prezbitere i đakone) predviđena posvetna molitva i polaganje ruku. ${ }^{6}$ Procvat literature o crkvenim službenicima uočljiv je početkom 4. stoljeća, nakon Konstantinova Milanskoga edikta 313. godine i Nicejskoga sabora 325. godine. Premda je tada započelo i zlatno razdoblje ranokršćanske literature, ipak se mogu izdvojiti neki razlozi procvata literature o klericima. Crkvene su službe tada dobro organizirane s jasnim ulogama i ovlastima, pa se je pojavila potreba da se one prodube teološki, eklezijalno i asketski. Prestankom progona kršćanstvo je dobilo slobodu i povlastice od civilne vlasti, što je uzrokovalo slabljenje duhovnosti klera. Klerici su se počeli više baviti profanim poslovima i materijalnim dobrima, stoga se je pojavila potreba za donošenjem normi za svakodnevni život klerika. Sve to potvrđuje i Jeronimovo pismo svećeniku Nepocijanu (Jeronim, 1996a, 413-441; Ad Nepotianum presbyterum, ep. 52) i spisi njegovih suvremenika koji su se bavili temama o svećeništvu: Obrana bijega Grgura Nazijanskoga inspirirala je Ivana Zlatosutoga da napiše knjigu $O$ svećeništvu, koju je sastavio nakon 386. godine, kada je bio zaređen za svećenika. Ivan Zlatousti ističe osobito uzvišenost i poteškoće svećeničkoga poziva, govori o potrebnim krepostima i svetosti. Ambrozije govori o zaređenim službenicima u svojem djelu De officiis ministrorum ("O dužnostima službenika"), napisanom po uzoru na Ciceronov spis De officiis.

U ovom članku želimo prikazati Jeronimovu misao o naravi i stupnjevima zaređenih službenika (đakonima, svećenicima i biskupima), ${ }^{7}$ posebice na temelju njegovih pisama, jer je upravo u pismima najjasnije izrekao svoj nauk o svećeništvu. Jeronim nije napisao posebnu knjigu o svećeništvu kao što su to učinili njegovi veliki suvremenici Grgur Nazijanski, Krizostom ili Ambrozije. Ograničenost članka nalaže da analizu usmjerimo na 116 pisama koje je Jeronim napisao, ${ }^{8}$ izostavljajući brojna druga njegova djela i biografske podatke, što zasigurno utječe na to da ovaj tekst nije cjelovit prikaz Jeronimova nauka o naznačenoj temi. Pisma su nastala u dugom razdoblju bez jasnoga i zajedničkoga povoda, a pisana su vrlo različitim osobama. Sadržaj pojedinih pisama uvjetovan je vremenom u kojem su napisana, osobama kojima su upućena i povodom njihova pisanja. $\mathrm{Na}$ sadržaj pisama često je utjecala kratkoća i polemičnost, kao i drugi razlozi koji

5 U pismu Tralijancima Ignacije piše: »Neka svi poštuju đakone kao Isusa Krista, biskupa također koji je slika Očeva, svećenike (prezbitere) kao vijeće Božje i kao kolegij apostola. Bez njih nema Crkve (Ignacije, 3,1).

6 Za dobar prikaz o zaređenim službenicima u 3. stoljeću usp. Scipioni, 1977.

7 O svećeničkoj duhovnosti usp. Mišić, 1990.

8 Zbirka Jeronimovih pisama sadržava 154 pisma, napisana između 374. i 419. godine. Od toga Jeronim je napisao 116, a 16 je pisama upućeno njemu. Među njima posebno su važna pisma koja je Jeronimu poslao Augustin. U zbirku je uključeno 14 pisama, od kojih je neka Jeronim preveo na latinski, neka su apokrifna. 
su bili povod pisanju. S druge strane, upravo je zbirka pisama, koja je nastala u dužem razdoblju, pogodna da se uoče i slijede eventualne razlike i razvoj Jeronimovih stavova o naravi i stupnjevima zaređenih službenika.

Nastojali smo izdvojiti tekstove koji obrađuju temu iz naslova ovoga članka, uz kratki prikaz sadržaja pisma, kada i zašto je pojedino pismo napisano te komu je bilo upućeno, kako bi što bolje razumjeli sam tekst i Jeronimovu misao. Nastojali smo objasniti kleričko nazivlje koje Jeronim koristi i usporediti ga, barem kratko, s prethodnom tradicijom. Potom slijedi analiza tekstova koji govore o naravi zaređenih službenika, različitim stupnjevima i njihovim međusobnim odnosima, a posebno između biskupa i svećenika.

\section{Zbirka pisama}

Jeronimova su pisma, nakon prijevoda Biblije (Vulgata), njegovi najčitaniji spisi. Pisma su napisana većinom za njegova boravka u Betlehemu. ${ }^{9}$ Veliku važnost i bogatstvo zbirke pisama očituje se u mnoštvu različitih tema o kojima je u njima riječ i brojnosti osoba s kojima se dopisivao (pape, biskupi i teolozi, svećenici i đakoni, monasi, djevice, udovice, dame iz visokoga društva, rodbina i prijatelji). Zbirka pisama veliki je dokaz različitosti Jeronimovih aktivnosti, bez obzira na njegov monaški život u pustinji. Ona su i izvor podataka o njegovu životu, karakteru i temperamentu, teološkim stavovima i njegovu odnosu prema poganskoj i kršćanskoj literaturi. Postoji više izdanja i prijevoda Jeronimovih pisama, a prvotisak je priredio glasoviti Erazmo Roterdamski. Tiskana su u latinskom originalu i prijevodima na suvremene jezike. ${ }^{10}$

Tematika o zaređenim službenicima spominje se u $27^{11}$ od 116 autentičnih Jeronimovih pisama, ponekad samo u naznakama, a u četiri pisma, koja kratko predstavljamo, opširnije je obrađena. U dva pisma (ep. 14 monahu Heliodoru i ep. 52 svećeniku Nepocijanu) obrađene su uglavnom asketske teme. Druga su dva pisma više doktrinarnoga i polemičkoga karaktera (ep. 69 laiku Oceanu i

9 Za detaljnu analizu Jeronimove zbirke pisama usp. Stoico, 1972.

10 Zbirka pisama dijelom je prevedena i na hrvatski jezik: Jeronim, 1908. Jedno od važnih izdanja bilo je ono francuskih benediktinaca A. Pougeta i J. Martiana (1690.-1706), sve do temeljnoga djela Vallarsi, Sancti Eusebbi Hieronymi Opera, Verona 1734.-1742., i kritičkoga izdanja Sancti Eusebii Hieronymi epistulae, CSEL (Corpus scriptorum ecclesiasticorum latinorum), vol. 54, 55, 56, Beč, 1910.-1918.

11 To su ova pisma: Ad Heliodorum monachum, ep. 14, no. 8-10; Ad Damasum, ep. 15, no. 2; Ad Damasum, ep. 16; Ad Marcum presbyterum Chalcide, ep. 17, no. 2; Ad Eustochium, ep. 22, no. 16 i 28; Ad Marcellam, ep. 41, no. 3; Ad Asellam, ep. 45, no. 3; Apologeticum ad Pammachium, ep. 49, no. 21; Ad Nepotianum presbyterum, ep. 52, no. 1-17; Ad Furiam de uiduitate seruanda, ep. 54, no. 5; Ad Heliodorum Epitaphium nepotiani, ep. 60, no. 10 i 14; Ad Fabiolam, ep. 64, no. 1, 2, 20 i 22; Ad Castricianum, ep. 68, no. 4-5; Ad Oceanum, ep. 69, no. 1-10; Ad Salvinam, ep. 79, no. 1; Ad Theophilum, ep. 82, no. 3-8 i 11; Ad Theophilum, ep. 88; Ad Augustinum, ep. 105, no. 4-5; Ad Riparium presbyterum, ep. 109, no. 2; Ad Augustinum, ep. 112, no. 15, 18 i 22; Ad Theophilum episcopum, ep. 114, no. 2; Ad Geruchiam de monogamia, ep. 123, no. 5 i 14; Ad Rusticum monachum, ep. 125, no. 8, 15 i 17; Ad Demetriadem, ep. 130, no. 7 i 17; Ad Cyprianum presbyterum de psalmo LXXXVIIII, ep. 140, no. 1; Ad Euangelum presbyterum, ep. 146, no. 1-2. 
ep. 146 svećeniku Evanđelu). Zanimljivo je da su posljednja dva pisma upućena osobama koje su boravile u Rimu, gdje je u to vrijeme postojala napetost između prezbitera i đakona i kada se raspravljalo o jedinstvu reda episkopa i prezbitera.

\subsection{Heliodoru monahu}

To pismo Jeronim je napisao iz pustinje dok je još bio laik. U njemu poziva prijatelja Heliodora da napusti rodni kraj i postane monah (Jeronim, 1996a, 4462, Ad Heliodorum monachum, ep. 14). ${ }^{12}$ Premda Jeronim hvali monaški život, ističući istovremeno teškoće života u gradu, nije uspio nagovoriti prijatelja da izabere monaški život. Heliodor je želio biti svećenik i biskup, pa zato Jeronim u pismu govori o svećeništvu. Za razliku od monaha koji se povlači u samoću i brine se za osobni duhovni život, svećenik svoju službu obavlja u gradovima i mora se prvotno brinuti za duhovni napredak povjerenih mu vjernika.

\subsection{Nepocijanu svećeniku}

To je najvažnije pismo za razumijevanje Jeronimovih stavova o svećeništvu, napose o svećeničkoj duhovnosti (Jeronim, 1996a, 413-441, Ad Nepotianum presbyterum, ep. 52). Pismo je napisano u Betlehemu 398., kao odgovor na više puta ponovljena pitanja mladoga svećenika Nepocijana. Čini se da se Jeronim bojao oštre kritike kakvu je doživio nakon pisma o djevičanstvu koje je uputio Eustohiji (Jeronim, 1996a, 143-211, Ad Eustochium, ep. 22): »Dragi Nepocijane, prošlo je deset godina kako su mi kamenovali onaj spis o djevičanstvu koji sam iz Rima uputio svetoj Eustohiji. Ti si me obvezao, iz Betlehema, da ponovo otvorim usta i izložim se, još jednom, klevetničkim napadima svakoga jezika « (Jeronim, 1996a, 413-441, Ad Nepotianum presbyterum, ep. 52, no. 17). Pismo Nepocijanu nije, međutim, izazvalo nikakvu polemiku. Na početku pisma Jeronim naširoko raspravlja o mudrosti i znanju, potom tumači značenje riječi klerik (clericus), pismo završava savjetima kakav bi život trebao da bude onih koji nose taj naziv. To je pismo i svojevrsno osobno svjedočanstvo duhovnosti samoga Jeronima.

\section{3. Осеапи}

To pismo upućeno je uglednomu laiku Oceanu, kojega je Jeronim upoznao za svojega boravka u Rimu (Jeronim, 1996a, 678-700, Ad Oceanum, ep. 69). U zbirci se nalaze četiri pisma koja su njemu upućena. Oceana je zanimao odgovor na pitanje o ponovnoj (drugoj) ženidbi jednoga španjolskoga biskupa koji je prvi put bio oženjen još prije krštenja. Odgovorivši na pitanje, Jeronim raspravlja o biskupstvu, posebice oslanjajući se na tumačenje teksta iz Pavlove poslanice Timoteju (1 Tim 3,1-7).

12 Eliodor iz Akvileje, vojnik pa monah, slijedio je Jeronima na Istok. Postavši biskupom, zaredio je za svećenika Nepocijana, sina svoje sestre. 


\subsection{Evangeliju}

Riječ je o nepoznatom svećeniku iz Rima kojemu je Jeronim napisao pisma 5 i 146 (Jeronim, 1996c, 308-312, Ad Euangelum presbyterum, ep. 146). Na početku pisma 146 Jeronim napominje da je čuo »da je neki pojedinac dospio do te ludosti da pretpostavlja đakona svećenicima«. To mu je bio poticaj da progovori o odnosu među zaređenim službenicima u Crkvi. Pismo ima polemički karakter. Važno je jer u njemu Jeronim najviše očituje svoje stav da među svećenicima i biskupima nema bitne razlike, da se razlika očituje samo u ulozi koju imaju u kršćanskoj zajednici, a ne u svetom redu.

Osim u ta četiri navedena pisma, ostali tekstovi povezani s temom ovoga članka razasuti su u drugim pismima, bez neke međusobne logičke povezanosti. Sadržaj tih tekstova poslužio je kao podrška ili pojašnjenje glavnih tekstova koji se nalaze u četiri spomenuta pisma.

\section{Nazivlje}

Ranokršćanska zajednica, svjesna posebnosti svojih institucija, od početka je imala poteškoću kako nazvati svoje službenike. Kršćanima je bio neprikladan kako poganski tako i židovski naziv svećenik za vjerske službenike, pa je prihvaćeno neutralno nazivlje. Teološko značenje i organizacijske uloge službenika u ranoj Crkvi brzo su se razvijali. Posebnu su ulogu imala dvanaestorica — koji su slijedili Isusa i bili svjedoci njegova javnoga djelovanja i naučavanja. U poslanici Efežanima $(2,20)$ spominju se proroci koji imaju određenu važnost u efeškoj zajednici, a spominje ih i starokršćanski spis Didahe. U jeruzalemskoj zajednici uz Jakova pojavljuju se apostoli i starješine (prezbiteri), slično kao u židovskom Sinedriju, i oni su donosili važne odluke za zajednicu (Dj 11,30; 21,28). U zajednicama koje je osnivao Pavao organizacijski sustav bio je sličan sinagogalnomu, a naziv za vođu zajednice nije točno određen. U poslanici Filipnjanima $(1,1)$ Pavao koristi grčki naziv episkop u smislu onoga koji pazi na zajednicu, a đakoni su njihovi "pomoćnici”. Pavao u svojim poslanicama ne spominje prezbitere. Krajem 1. stoljeća zajednice uglavnom vode skupine prezbitera, koji imaju organizacijsku i pastoralnu ulogu u mjesnim zajednicama (usp. Dj 14,23, 20,17.23-30; 1 Pt 5,1; 1 Tim 3,1-7, 5,17-20; Tit 1,5-11; Jak 5,14; 2 Iv 1,1; 3 Iv 1,1). Početkom 2. stoljeća, kako čitamo u poslanicama Ignacija Antiohijskoga, službenici su podijeljeni u tri skupine: episkopi, prezbiteri i đakoni — zanimljivo je da samo kod Ignacija Antiohijskoga u to vrijeme nalazimo trodijelnu hijerarhijsku strukturu službenika. Pojmovno, sadržajno i kako se ulazilo u službu, nejasno su definirani kroz cijelo 2. stoljeće. Za ustroj i nazivlje zaređenih službenika odlučujuće je 3. stoljeće, pa je u Jeronimovo vrijeme, u drugoj polovici 4. stoljeća, nazivlje i ulazak u službu bio prilično jasno određen (usp. Vanhoye, 1980; Schillebeeckx, 1982, 13-69; Dianich, 1983). 


\subsection{Clericus}

Pogledajmo ukratko nazivlje koje Jeronim koristi u svojim pismima. Pozivajući se na Bibliju i Filona, naziv clericus Jeronim izvodi iz značenja riječi clericus (baštinik), tako je i Bog (clerus, baština) koja pripada levitima, a vjernici (narod Božji) su Božja Baština. Oni koji imaju neku službu upravljanja u kršćanskoj zajednici označeni su zajedničkim nazivom kler. ${ }^{13}$ Naziv kler (clerus), kao i narod (plebs) Jeronim koristi u kolektivnom smislu, označavajući sve službenike u kršćanskim zajednicama. Taj naziv pomaže općemu razumijevanju crkvene službe, ujedno izriče i bit onih koji su u službi Crkvi. ${ }^{14}$

\subsection{Episcopus, presbyter, diaconus (biskup, svećenik, đakon)}

U prvim kršćanskim zajednicama postojali su nadzornici ili episcopus (biskupi), starješine ili prezbyteroi (svećenici) koji upravljaju zajednicom i đakoni posvećeni služenju u zajednici. ${ }^{15}$ To nazivlje ostalo je temeljno i najviše korišteno $\mathrm{u}$ narednim stoljećima, samo je precizirano i teološki produbljeno. Jeronim u svojim pismima uglavnom koristi nazivlje grčkoga podrijetla (episcopus, prezbyter, diaconus). Problem nije u njihovu korištenju, nego u teološkom sadržaju i značenju. Što se tiče đakona, nema posebnih problema: naziv je utemeljen na svjedočenju Svetoga pisma: »Neka su svjesni razloga zbog koji su postavljeni đakoni, neka čitaju Djela apostolska i neka se prisjete svojega stanja « (Jeronim, 1996c, 311-312, Ad Euangelum presbyterum, ep. 146, no. 2). Problemi u sadržaju pojma prezbyter i episcopus proizlaze iz Jeronimova mišljenja da nema bitne razlike među njima. »U obje poslanice (1 Tim 3,1-7, Tit 1,5-9) i episkopi i prezbiteri prema starima su jednaki episkopi i prezbiteri, jer ono je naziv za dostojanstvo ovo za dob «. ${ }^{16}$ Nazivi prezbyter i episcopus ipak za Jeronima nisu istoznačnice koje se koriste ne mareći za okolnosti i osobe. Oni se odnose na čast i ulogu koju svaki ima u Crkvi, a ne na stupanj pripadnosti svetomu redu. Jeronim u pismu biskupu Augustinu piše: »Budi dobro, predragi prijatelju, sine moj po dobi i oče po dostojanstvu «(Jeronim, 1996a, 35, Ad Paulum senem concordiae, ep. 10, no. 5).

\subsection{Sacerdos, sacerdotio}

Već smo spomenuli da se u novozavjetnim spisima ne primjenjuje svećeničko nazivlje na apostole ni na druge službenike: prezbitere, episkope i đakone. To se nazivlje koristi samo za označavanje Krista i svećeničkoga naroda. Korištenje

13 Tu razliku jasno ističe u trećem stoljeću Ciprijan: »clerus et plebs fraternitas omnis« (Ciprijan, 1871, 615, ep. 51, no. 1).

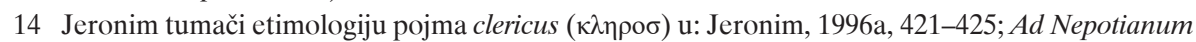
presbyterum, ep. 52, no. 5).

15 Ta trostruka struktura crkvenih službenika, i sami nazivi, prisutni su već u spisima Novoga zavjeta (Leonardi, 1977).

16 »In utraque epistula (1 Tim 3,1-7; Tit 1,5-9) sive episcopi sibe prezbiteri - quamquam apud veteris idem episcopi et prezbiteri fuerunt, quia illud nomen dignitatis est hoc aetatis«(Jeronim, 1996a, 683; Ad Oceanum, ep. 69, no. 3). 
svećeničkoga nazivlja na zapadu počinje u 3. stoljeću s Tertulijanom i Ciprijanom te se je primjenjivalo na episkope (biskupe) koji su bili redoviti predvoditelji liturgije, predsjedali nedjeljnoj euharistiji, molitvenim slavljima. Hipolit u spisu Apostolska tradicija (br. 3 i 34) naziv sacerdos koristi za biskupa, a nikada taj naziv ne koristi za prezbitera. U 4. stoljeću, osobito u drugoj polovici, naziv sacerdos (svećenik) sve je češće korišten i za prezbitere, osobito zato što su i prezbiteri sve više slavili liturgiju, poučavali u zajednicama i obnašali službe koje su nekada bile pridržane samo biskupima. ${ }^{17}$ Jeronim koristi nazive sacerdos i sacerdotio kako za biskupe tako i prezbitere, ponekad u nejasnom smislu, premda ih ne koristi osobito često. Jeronim koristi i druge nazive a da ih ne tumači, primjerice pontifex Cristi (Jeronim, 1996a, 430-431, Ad Nepotianum presbyterum, ep. 52, no. 9; Jeronim, 1996b, 107-119, Ad Theophilum, ep. 82, no. 11). Prezbiteri i episkopi su ministri Cristi (Jeronim, 1996a, 431-433; Ad Nepotianum presbyterum, ep. 52, no 10), succedentes Cristi (Jeronim, 1996b, 117-119, Ad Theophilum, ep. 82, no. 11; Jeronim, 1996c, 105-107, Ad Auitum, ep. 124, no. 8) ili apostolorum successores (Jeronim, 1996c, 308-311, Ad Euangelum presbyterum, ep. 146, no. 1). Kad je Jeronim pisao biskupu Augustinu nazvao ga je papa, a taj je naziv u afričkoj crkvi koristio već Ciprijan. ${ }^{18}$

\subsection{Ordinatio (ređenje)}

Taj je naziv u Rimskom Carstvu označavao ulazak ili imenovanje u carsku službu. Tertulijan ga je prvi koristio u kršćanskom smislu za crkvene službe. ${ }^{19}$ Samo ređenje (ordinatio) nije povezano s polaganjem ruku. Termin ordinatio podrazumijeva poziv i poslanje od strane zajednice. U zapadnoj crkvi uz ordinatio (ređenje) koristio se je i naziv impositio manuum (polaganje ruku). Jeronim koristi izraz ordinatio za ulazak među kler, u klerički stalež. Da bi netko postao klerik, Jeronimu je prvotno važan izbor i poslanje koje daje zajednica, a polaganje ruku samo je potvrda toga izbora i poslanja. U svojim pismima Jeronim ne tumači navedeno nazivlje niti opisuje obred ređenja.

\section{Narav i stupnjevi službenika}

Ukratko smo predstavili tekstove iz Jeronimovih pisama u kojima se govori o zaređenim službenicima te istaknuli neke važnije pojmove. Recimo nešto o naravi zaređenih službenika, njihovu odnosu s apostolima, ulozi u zajednici i o

17 O Jeronimovu korištenju naziva sacerdos i sacerdotio usp. Ad Heliodorum monachum, ep. 14, no. 9; Ad Eustochium, ep. 22, no. 6; Apologeticum ad Pammachium, ep. 49, no. 21; Ad Nepotianum presbyterum, ep. 52, no. 5-7 i 16; Ad Heliodorum Epitaphium nepotiani, ep. 60, no. 10; Ad Fabiolam, ep. 64, no. 20; Ad Oceanum, ep. 69, no. 9; Ad Theophilum, ep. 82, no. 11 i 18; Ad Geruchiam de monogamia, ep. 123, no. 5; Ad Euangelum presbyterum, ep. 146, no. 1-2.

18 »Optimus te beatissime ac glorisissime papa semper in Domino bene volere et nostri meminisse« (Ciprijan, 1871, 556, ep. 30, no. 6).

19 »Differentiam inter ordinem et plebem constituit ecclesiae auctoritas et honor per ordinis consenssus sanctificatos dei « (Tertulijan, 1954, 1024-1035, De Exhortatione castitatis, 7, 3). 
različitim stupnjevima službenika. Posebno nas zanima kako Jeronim obrazlože svoj stav da između biskupa i svećenika, u pripadnosti svećeničkomu redu, nema bitne razlike. U čemu je bit zaređenih službenika Jeronim je izrekao, u vrijeme dok je još bio laik, ${ }^{20}$ u pismu Heliodoru i taj tekst predstavlja srž njegove teologije o svećeništvu koji nije mijenjao ni kasnije. On piše: »Bože sačuvaj da bih o njima rekao nešto loše, jer oni su nasljednici apostola, svojim ustima posvećuju tijelo Isusovo. Po njima mi bivamo kršćani. Oni, na neki način, sude prije Sudnjega dana, jer posjeduju ključeve kraljevstva nebeskoga, i svojom uzdržljivom čistoćom čuvaju nepovrijeđenu Zaručnicu Kristovu« (Jeronim, 1996a, 55-57, Ad Heliodorum monachum, ep. 14, no. 8). Analizom spomenutoga teksta moguće je izdvojiti nekoliko bitnih odrednica.

1. Oni su nasljednici Apostola. Tu misao nalazimo već kod Ignacija Antiohijskoga, ${ }^{21}$ a Jeronim navodi kao prvu karakteristiku zaređenih službenika (svećenika). Isto poimanje nalazimo i u drugim pismima, a razlike ovise o tom je li pisma napisao kao laik ili klerik. Kao laik nije pravio razlike među različitim stupnjevima zaređenih službenika, svi su nasljednici apostola. Kasnije je isticao da su to samo episkopi i prezbiteri (Jeronim, 1996a, 533-535, Ad Paulinum presbyterum, ep. 58, no. 5), a đakoni su nasljednici sedmorice koji su, nakon polaganja ruku, određeni za služenje kod stolova i udovicama. Ulogu koju su apostoli imali u Crkvi sada imaju episkopi i prezbiteri: propovijedati, voditi i organizirati zajednicu vjernika. To je važna i teška zadaća, a ne osobni privilegij. Iz uloge koju episkopi i prezbiteri imaju u Crkvi, kao nasljednici apostola, izvire njihovo dostojanstvo, ali i poteškoće: »Nije lako stajati na Pavlovu mjestu i zauzimati stupanj onih koji vladaju s Kristom « (Jeronim, 1996a, 58, Ad Heliodorum monachum, ep. 14, no. 9).

2. Svojim ustima posvećuju tijelo Isusovo. Za Jeronima posebno je važna povezanost svećenika s Euharistijom i po tome se bitno razlikuju od đakona. Povezanost s Euharistijom ujedinjuje svećenike i biskupe (Jeronim, 1996c, 308-311, Ad Euangelum presbyterum, ep. 146, no. 1). Premda Jeronim u pismima ne iznosi cjelovit nauk o Euharistiji niti tumači kako se dolazi do moći posvećenja Euharistije, on jasno ističe povezanost Kristova tijela u Euharistiji i Crkve, Kristova mističnoga tijela. Euharistija ujedinjuje i izgrađuje Crkvu, znak je jedinstvenosti i zajedništva. Euharistija nije privatna stvar zaređenih službenika (Jeronim, 1996a, 696-699; Ad Oceanum, ep. 69, no. 9). Ona je naprotiv znak ljubavi i mira među ljudima (Jeronim, 1996a, 186-189, Ad Eustochium, ep. 22, no. 29; Jeronim, 1996b, 108-111, Ad Theophilum, ep. 82, no. 2-3).

3. Po njima mi bivamo kršćani. Jeronim misli na krštenje, jer krstiti sve narode temeljna je zadaća koju je Isus zapovjedio apostolima.

20 Pismo Heliodoru napisano je 376. iz kaldejske pustinje, a Jeronim je zaređen za svećenika 379. (?), za vrijeme boravka u Antiohiji (Jeronim, 1996a, 44-62, Ad Heliodorum monachum, ep. 14).

21 Usp. Ignacije, Tral., 3,1; Smir., 8,1. 
4. Na neki način, sude prije Sudnjega dana. Tu moć zaređenih službenika Jeronim povezuje s obećanjem Petru: »Tebi ću dati ključeve kraljevstva, pa što god svežeš na zemlji, bit će svezano i na nebesima, a što god razriješiš na zemlji, bit će razriješeno i na nebesima« (Mt 16,19). S jedne strane ističe moć suđenja, a s druge odgovornost za grešnika, bilo da ga se nastoji obratiti bilo da se za njega moli. »Ako padne monah, za njega će se moliti svećenik (sacerdos)«(Jeronim, 1996a, 58, Ad Heliodorum monachum, ep. 14, no. 9).

5. Svojom uzdržljivom čistoćom čuvaju nepovrijeđenu Zaručnicu Kristovu. Tim je riječima Jeronim istaknuo važnost povezanosti klerika i Crkve. Njihov život morao bi biti posvećen službi kršćanskoj zajednici.

Zaključno moglo bi se kazati da Jeronim bit zaređenih svećenika vidi u tri temeljne činjenice kršćanske vjere: a) u njihovoj povezanosti s apostolima, čiji su nasljednici; b) u njihovoj moći da slave sakramente, posebno euharistiju i krštenje; c) u povezanosti zaređenih službenika s Crkvom. Iz toga izvire njihovo dostojanstvo i moć koju imaju u kršćanskim zajednicama.

\section{Episkopi i prezbiteri}

Jeronimovo mišljenje da među episkopima i prezbiterima nema bitne razlike prilično je usamljeno u literaturi 4. stoljeća. ${ }^{22}$ On tvrdi da među episkopima i prezbiterima postoji jedinstvo reda, razlike nisu teološke, nego sociološke naravi, ovisno o ulozi koju svatko ima u zajednici. Da bi potkrijepio svoj stav, naveo je iste moći episkopa i prezbitera, tradiciju i neke citate iz Novoga zavjeta.

\subsection{Jedinstvo u ređenju}

Jeronim odlučno brani jedinstvo i posebnost episkopata i prezbiterata u odnosu na đakonat. Da bi naglasio uzvišenost prezbiterata i episkopata, on umanjuje važnost đakonata: »što im je da tu službu određenu za služenje za stolovima i udovicama [...] stavljaju iznad onih koji svojom molitvom posvećuju Tijelo i Krv Kristovu« (Jeronim, 1996c, 308-311, Ad Euangelum presbyterum, ep. 146, no.

22 Takvo mišljenje ima samo pisac poznat pod imenom Ambroziaster — izmišljeno ime nepoznatoga autora komentara trinaest Pavlovih poslanica, koji su najvjerojatnije sastavljeni u Rimu u drugoj polovici 4. stoljeća. Većina je srednjovjekovnih rukopisa te komentare pripisivala Ambroziju iz Milana, no kada je to dovedeno u sumnju, nepoznati autor tih spisa nazvan je Ambroziaster. Nije poznat identitet autora niti je poznato njegovo podrijetlo, tj. nije jasno je li rođenjem Grk ili nešto drugo. Tko se krije iza imena Ambroziaster još uvijek je zaogrnuto velom tajne. Novija istraživanja pripisuju mu i druge spise: Quaestiones Veteris et Novi Testamenti sačuvano pod Augustinovim imenom, anonimni komentar 24. poglavlja Matejeva evanđelja, fragmente De Petro apostolo e Incipit de tribus mensuris, Lex Dei sive Mosaicarum et Romanarum legum collatio, De bello judaico. Ostaje zagonetka i mogući utjecaji na Ambroziasterovo učenje te njegov utjecaj na Pelagija i Augustina. 
1). ${ }^{23}$ Nasuprot tomu, Jeronim ne vidi bitne razlike između episkopa i prezbitera: »Svećenik i biskup [prezbyter i episcopus] samo su nazivi koji označuju jedno dob, a drugo čast « (Jeronim, 1996c, 311-312, Ad Euangelum presbyterum, ep. 146, no. 2), »ta dva naziva, biskup i prezbiter, istinu govoreći, u prva vremena bijahu sinonimi: prvi se naziv odnosi na dostojanstvo, drugi na dob « (Jeronim, 1996a, 683; Ad Oceanum, ep. 69, no. 3). ${ }^{24}$ Jeronim, dakle, smatra da su nazivi episcopous i prezbyter sinonimi koji izražavaju isti sadržaj i značenje. »Mi znamo da je isti odnos između Arona i njegovih sinova, kao između biskupa i njegovih svećenika [prezbyteros]. Samo je jedan Gospodin, jedan hram: također i jedinstvo službenika« (Jeronim, 1996a, 426-428; Ad Nepotianum presbyterum, ep. 52, no. 7). Kako je već rečeno, Jeronim je prilično usamljen u tom svojem stavu u usporedbi s drugim ranokršćanskim piscima prije njega i njegovim suvremenicima. Tako je primjerice za Krizostoma biskup snagom ređenja viši od prezbitera. ${ }^{25}$ Isto mišljenje i istu argumentaciju kao Jeronim ima samo Ambroziaster. ${ }^{26}$

Tri su osnovna izvora iz kojih Jeronim izvodi svoju teoriju: ista moć koju imaju episkopi i prezbiteri, biblijski tekstovi (osobito Pavlove poslanice) i tradicija. 1. »U stvari, ako se ne gleda na dobivenu službu, što drugo čini biskup, a ne bi mogao činiti neki svećenik (prezbiter)« (Jeronim, 1996c, 290-291, Ad Augustinum, ep. 141, no. 1). Jednakost moći očituje se prije svega u euharistijskoj službi. Jeronim ne raspravlja o mogućnosti da prezbiter zaredi nekoga drugoga, a upravo u toj mogućnosti mnogi crkveni oci vide razliku između episkopa i prezbitera. ${ }^{27} 2$. »Ne kaže li jasno apostol da su prezbiteri i biskupi iste osobe « (Jeronim, 1996c, 308-311, Ad Euangelum presbyterum, ep. 146, no. 1). Da bi potkrijepio tu svoju tvrdnju, Jeronim citira: Fil 1,1; Dj 20,28; 1 Tim 4,14; 1 Pt 5,1; 2 Iv 1,1; 3 Iv 11,3. Potvrdu svojemu stavu da između episkopa i prezbitera nema bitne razlike Jeronim nalazi i u tradiciji, koju on ne ograničava samo na kršćansku, nego i na starozavjetnu židovsku tradiciju, uspoređujući svećenstvo Staroga zavjeta sa službenicima u Crkvi. »Znamo da je apostolska tradicija preuzeta od Starog zavjeta. Zar nisu u hramu bili Aron, njegovi sinovi i leviti? Isto vrijedi s obzirom na biskupe, svećenike i đakone « (Jeronim, 1996a, 426-428; Ad Nepotianum presbyterum, ep. 52, no. 7; Jeronim, 1996c, 311-312, Ad Euangelum presbyterum, ep. 146, no. 2). Jeronim ne tvrdi da je narav židovskoga svećeništva ista s crkvenim službenicima niti da su službenici u Crkvi zamijenili svećenika Staroga zavjeta. Postoji ontološka razlika među njima. Naime svećeništvo se kod Židova prenosilo rađanjem, a

23 Već Ignacije Antiohijski đakone stavlja na treće mjesto u hijerarhiji, a slično Hipolit u Apostolskoj tradiciji (br. 8), Ciprijan (1871, str. 469-470, ep. 3, no. 1) i Nicejski sabor: »Đakoni su sluge biskupima i podložni prezbiterima« (325. - CPG IV, 852-857).

24 Prema Jeronimu, poslanice Titu i Timoteju govore o ređenju episkopa i đakona tako što su među episkope uključeni i prezbiteri. Slično nalazimo i u drevnom spisu Didahe $(\mathrm{XV}, 1)$ i Klementovoj poslanici Korinćanima (XL,4).

25 Usp. Krizostom, Hom., 11,1 in Tim.: PG 62,553.

26 Usp. Ambroziaster, Quaestiones Veteris et Novi Testamenti 101, PL 35, 2305-2306-; In 1 Tim. 3,8-10, PL, 17,496.

27 Usp. Trad. apost., 8; Epifanije, Adversus haereses Panharium, MG, 42 508; Cost. Apost., MG, 1,1124 . 
poslanje u kršćanskoj zajednici je izbor i poslanje Crkve, koje se prenosi, počevši od apostola, polaganjem ruku. Jeronim uspoređuje Arona i njegove sinove, koji pripadaju svećeničkomu staležu, s episkopima i prezbiterima, a levite, koji su bili poslužitelji u hramu, uspoređuje s đakonima, koji su od početka predviđeni za služenje u zajednici (Jeronim, 1996c, 311, Ad Euangelum presbyterum, ep. 146, no. 2).

Prema Jeronimu, i prethodna kršćanska tradicija, počevši od Novoga zavjeta, čvrsto potvrđuje da nema bitne razlike između episkopa i prezbitera. Kako bi to potvrdio, navodi više tekstova i crkvenu praksu u Aleksandriji: »U Aleksandriji, naime, već od Marka evanđelista sve do biskupa Herakla i Dionizija, prezbiteri su uvijek izabirali jednoga između sebe, i postavljali na viši stupanj te ga nazivali biskupom« (Jeronim, 1996c, 308-311, Ad Euangelum presbyterum, ep. 146, no. 1). ${ }^{28}$

\subsection{Različite uloge u Crkvi}

Premda Jeronim ne vidi bitnu razliku u pripadnosti svetomu redu između episkopa i prezbitera, on ne dovodi u pitanje različitost uloga i službi koje oni obavljaju u Crkvi. On jasno razlikuje ulogu i poslanje biskupa i svećenika u kršćanskoj zajednici, ali naglašava da se ne temelje na svetom redu, nego na tradiciji i na organizacijskim potrebama Crkve (Jeronim, 1996c, 308-311, Ad Euangelum presbyterum, ep. 146, no. 1). Budući da je Crkva također i ljudska zajednica, ona zahtijeva organizaciju sličnu drugim ljudskim zajednicama: »Svaka crkva ima samo jednoga biskupa, smo jednoga nadprezbitera [archiprezbyteri], samo jednoga arhiđakona. Cjelokupni crkveni ustroj oslanja se na svoje poglavare. Tako je na brodu samo jedan zapovjednik, u kući samo jedan otac, svaka vojska, bez obzira koliko je brojna, očekuje znak od samo jednoga « (Jeronim, 1996b, 133-134, Ad Rusticum monachum, ep. 125, no. 15). Posebna uloga koju Jeronim namjenjuje biskupu, kao poglavaru Crkve, jest da su oni nasljednici apostola i branitelji pravovjerja (Jeronim, 1996b, 141-142, Ad Theophilum, ep. 88) i zato se čudi što neki biskupi ne čine ništa protiv svećenika svoje biskupije koji propovijedaju heretički nauk i što ne razbije svojom »apostolskom batinom posudu beskorisnu « i tako spasi njegovu dušu (Jeronim, 1996b, 353-354, Ad Riparium presbyterum, ep. 109, no. 2). Posebno važnu ulogu u obrani pravovjerja Jeronim priznaje papi (rimskomu biskupu) (Jeronim, 1996a, 63-64, Ad Damasum, ep. 15, no. 2). Petar, to jest biskup Rima, predstavlja Krista kao poglavar Crkve, stoga Jeronim želi biti s njime u bliskom zajedništvu. Nije riječ samo o strogo juridičkom (pravnom) zajedništvu, nego također u jedinstvu u nauku i vjernosti rimskomu autoritetu. Jeronim, ipak, ne daje rimskoj biskupiji nikakvu "apriornu" prednost u vezi s obvezom pravovjerja i vjernosti Kristu. Kao poglavari mjesnih kršćanskih zajednica, biskupi su međusobno jednaki u vlasti i dostojanstvu, a temelj jednakosti nalazi

28 O jednakosti između episkopa i prezbitera, koja proizlazi iz kršćanskih svjedočanstva privih stoljeća usp. (Lécuyer, 1957; Botte, 1956). Prikazani su patristički i liturgijski tekstovi sve do sabora u Kalcedonu. 
se u pripadnosti istomu svećeništvu: »biskup, bez obzira gdje se nalazi, [...] uvijek ima isti stupanj, kao i isto svećeništvo. Ono što nekoga biskupa čini viđenijim je li siromašan i ponizan ili bogat ili moćan, a svi ostali nasljednici su apostola « (Jeronim, 1996c, 308-311, Ad Euangelum presbyterum, ep. 146, no. 1).

\subsection{Moć utemeljena na ljubavi}

Biskup svoju vlast mora obavljati u ljubavi, kao otac, a ne kao gospodar, to se posebno odnosi na klerike koji, nakon što su odbacili svjetsku karijeru, žele imati mir. Također, potrebno je voljeti biskupe, a ne bojati ih se (Jeronim, 1996b, 119; Pammachii et Oceani ad Hyeronimum, ep. 83, no. 3). Upravo je u tom bitna razlika između duhovne i zemaljske moći. Prva upravlja s ljubavlju, druga nametanjem volje (Jeronim, 1996a, 570-571, Ad Heliodorum Epitaphium nepotia$n i$, ep. 60, no. 16). S druge strane, Jeronim se oštro protivi neopravdanoj kritici biskupa: »Stidim se kazati: iz jame naših ćelija, osuđujemo svijet. Valjamo se u kostrijeti i pepelu, a svojom presudom osuđujemo biskupe! (Jeronim, 1996a, 70-72, Ad Marcum presbyterum Chalcide, ep. 17, no. 2). Ponekad je, ipak, i sam oštar kritičar biskupa, osobito ako ih smatra hereticima: »Nisu svi biskupi biskupi. Misliš na Petra, sjeti se također i Jude« (Jeronim, 1996a, 58, Ad Heliodorum monachum, ep. 14, no. 9). ${ }^{29}$ Svoj stav o biskupima Jeronim je sažeo u 82. pismu, koje je napisao aleksandrijskomu patrijarhu Teofilu: »Ako smo mi ostavili naše zavičaje zato da bismo mogli živjeti u polju i pustinji, daleko od svakoga rivalstva, i da bismo mogli slaviti svećenike [pontefici] Kristove (one samo, međutim, koji propovijedaju pravovjernu vjeru), ne u servilnom strahu, nego štujući ih kao biskupe, a ne da budemo prisiljeni činiti to kao sluge — možda pod nekim drugim imenom — kao osobe koje nemaju nikakvu nakanu služiti. Mi se ne osjećamo, u nutrini, tako ponosni da se pretvaramo da znamo dužnosti koje imamo prema Kristovim svećenicima [Sacerdotibus Cristi]. Znamo naime tko ih prima, ne prima njih u strogom smislu, nego prima osobito Onoga od kojega jesu biskupi. Kada su poštivani kao takvi, neka ne traže drugo! Neka znaju da moraju biti očevi, a ne gospodari« (Jeronim, 1996b, 117-119; Ad Theophilum, ep. 82, no. 11).

Da bismo bolje razumjeli navedeni Jeronimov tekst, treba imati na umu da je to 82. pismo napisano iz Betlehema početkom 397. godine i upućeno aleksandrijskomu patrijarhu Teofilu, koji je nastojao posredovati u polemici između Jeronima i jeruzalemskoga biskupa Ivana. U pismu Jeronim odgovara pokazujući živu želju da se pomiri s biskupom Ivanom, obrazlažući također i svoje ponašanje prema episkopima. Jeronim ne poriče obvezu poslušnosti biskupima, ali ne u "sluganskom strahu", nego kao ocima. Navodi i uvjete za poslušnost: da je biskup pravovjeran i svjestan vlastitih dužnosti, osobito prema onima koji su prezreli svjetsku karijeru i onima koji se žele potpuno posvetiti monaškomu životu.

29 Zanimljivo je da se slična misao može naći i kod Augustina: »biskup koji ne voli služiti, spreman dati i svoj život, po uzoru na Krista, za svoju braću, nije biskup. Evo kakav mora biti dobar biskup, u protivnom ni nije niti biskup [...], da naziva se biskup, ali nije biskup, i prazno je smislom titul koji ima (Augustin, Serm., 32, 4, Miscellanae Agostiniana, Vol. I, p. 566). 


\section{Zaključak}

U ovom su radu predstavljeni tekstovi iz zbirke pisama sv. Jeronima u kojima on govori o naravi i stupnjevima zaređenih službenika. Izabrali smo njegova pisma jer o toj temi u njima govori opširnije nego u drugim svojim djelima. Teme o svećeništvu ipak nisu dominantne. Među 116 autentičnih pisma u samo njih 27 nalaze se kratki tekstovi ili opaske, a samo su četiri pisma tematski povezana uz svećeništvo. Treba ipak naglasiti da tekstovi koje nalazimo u Jeronimovim pismima nisu dostatni da bi predstavili, u cijelosti, Jeronimov nauk o zaređenim službenicima niti mogu dati dovoljno elemenata za prikaz cjelokupne panorame ministerijalne problematike na prijelazu 4. i 5. stoljeća.

S obzirom na podjelu službi i terminologiju o kojoj govori, Jeronim se ne razlikuje od one koja se tada koristila. On razlikuje tri stupnja: episkop, prezbiter i đakon te većinom koristi upravo te grčke nazive. Koristi također latinski naziv sacerdos i sacerdotio te ga primjenjuje na episkope i prezbitere, ali ne na đakone. Nejasnoća u korištenju toga naziva proizlazi iz Jeronimova stava da između episkopa i prezbitera nema bitne razlike. Treba imati na umu da on vrlo rijetko koristi nazive sacerdos i sacerdotio, a kada želi jednim nazivom ujediniti sve, zaređene službenike koristi naziv clericus. Jeronim je dao i lingvističko (etimološko) tumačenje naziva clericus, izvodeći iz njega bitnu oznaku službenika: klerik naime naznačuje onoga koji pripada Bogu i komu je Bog baština.

Da bi se postalo službenikom u Crkvi, prema Jeronimu, odlučan je izbor i poslanje zajednice, a polaganje ruku samo je potvrda poslanja. Jeronim rijetko koristi izraz polaganje ruku (impositio manuum), a puno češće riječ ređenje (ordinatio). U pismima se ne nalazi nikakav opis obreda ređenja. U ovom smo radu promotrili tekstove iz Jeronimovih pisama u kojima on govori o biti i različitim stupnjevima zaređenih službenika, njihovu međusobnom odnosu i ulogama koje imaju u kršćanskoj zajednici. Jeronim bit zaređenih službenika (episkopa i prezbitera) vidi u njihovoj povezanosti s apostolima, sakramentima i Crkvom. Đakoni su nasljednici sedmorice, koje su apostoli izabrali i odredili za služenje u zajednici. Episkopi i prezbiteri, međutim, u zajednici zauzimaju ulogu apostola, njihovi su nasljednici u moćima i dostojanstvu. Poput apostola, episkopi i prezbiteri imaju zadaću propovijedati, organizirati i voditi zajednicu vjernika. Jeronim jako ističe povezanost zaređenih službenika s Crkvom i obvezom služenja. Oni moraju biti poput otaca, a ne gospodara. Najvažniju ulogu koju imaju u zajednici slavljenje je sakramenata, napose euharistije. Moguće je naći tek naznake i za ostale sakramente, osobito krštenja i pomirenja.

Nazivlje koje Jeronim koristi jednako je onomu koje se u to doba koristilo, bitnija je razlika u teološkom sadržaju koji on pridaje pojedinomu nazivu, a posebno episcopus i prezbyter. Jeronimova je posebnost u tom da on odlučno niječe bitnu razliku u stupnju svetoga reda između episkopa i prezbitera, a razlika je u službi koju svaki ima u Crkvi. Razlika je, dakle, više sociološka nego ontološka. Svoj stav dokazuje ističući da episkopi i prezbiteri imaju iste moći, što dokazuje navodeći biblijske tekstove i tradiciju. Poteškoća je u tom što Jeronim nije razra- 
dio i produbio nijedan od navedenih argumenata. On primjerice ističe da episkopi i prezbiteri imaju moć slavljenja Euharistije, ali ne govori o mogućnosti da prezbiter zaredi drugoga prezbitera. On navodi i više biblijskih tekstova, osobito iz Pavlovih poslanica, no bez tumačenja tih tekstova koji, prema njemu, jasno pokazuju jedinstvo svetoga reda. Ni pozivanje na tradiciju nije dovoljno obrazloženo. Jeronim kaže: »prema starima bili su jednaki episkopi i prezbiteri«,30 ali jedini konkretni primjer koji navodi praksa je iz zajednice u Aleksandriji, gdje su prezbiteri između sebe birali jednoga kojega su postavili na viši stupanj i nazvali ga episkopom.

Premda Jeronim smatra da ne postoji bitna razlika u svetom redu između episkopa i prezbitera, ne niječe različitost ulogâ i službi koje ostvaruju u Crkvi. Tvrdi, međutim, da korijeni te različitosti nisu teološki, nego društveni i ustrojbeni. Budući da je Crkva također ljudska zajednica, i ona mora imati ustroj sličan drugim ljudskim zajednicama, primjerice poput vojske ili posade broda koja sluša zapovjednika. Slično u Crkvi biskup je glava zajednice.

Nadamo se da je ovim prikazom dovoljno iscrpno obrađena zanimljiva tema iz bogate književne ostavštine velikoga kršćanskoga pisca sv. Jeronima, prigodom 1600. obljetnice njegove smrti. U članku nismo govorili o do sada nepoznatom stavu sv. Jeronima o crkvenim službenicima. Pokušali smo detaljnije izdvojiti tekstove iz njegovih pismima koji govore o naravi i stupnjevima zaređenih službenika te obraditi ih pod nekoliko vidika. Nije nam bila namjera cjelovito predstaviti Jeronimovu teologiju o svetom redu. Uzeti su u obzir samo tekstovi iz njegovih pisama. Bilo bi vrlo zanimljivo podrobnije prikazati povijesne okolnosti hijerarhijskoga ustroja, osobito u rimskoj crkvi, te širu usporedbu Jeronimovih stavova s njegovim suvremenicima, osobito s Ambrozijastrom, Grgurom Nazijanskim i Ivanom Zlatoustim. Nadam se da će 1600. obljetnica smrti sv. Jeronima biti poticaj za nove prikaze tema iz njegove bogate književne ostavštine.

\section{Literatura:}

Botte, Bernard (1956). Presbyterium et Ordo episcoporum. Irenikon, 29, 5-27.

Boularand, Ephrem (1971). Le sacerdoce mystère de crainte et d'amour chez saint Jean Chrysostome. Bulletin de Littérature Ecclésiastique, 72, 3-36.

Bulić, Frane (1920). Stridone luogo natale di s. Girolamo, studio storico geografico. U: Vincenzo Vannutelli (ur.), Miscellanea Gerominiana: Scritti varii pubblicati nel XV centenario dalla morte di San Girolamo (str. 253-330). Rome: Tipografia poliglotta vaticana.

Ciprijan (1871). S. Thasci Caecili Cypriani opera omnia: Pars II: Epistulae. Uredio W. Hartel. Corpus scriptorum ecclesiasticorum latinorum (CSEL), vol. 3/2. Vindobonae: Österreichischen Akademie der Wissenschaften.

Dianich, Severino (1983). Teologia del ministero ordinato. Cinisello Balsamo: San Paolo.

Greshake, Gisbert (1982). Priestersein: Zur Theologie und Spiritualität des pristerlichen Amtes. Fraiburg in Breisgau: Herder.

30 »Quamquam apud veteres idem episcopi et presbyteri fuerunt « (Jeronim, 1996a, 683, Ad Oceanum, ep. 69 , no. 3). 
Gryson, Roger (1968). Le prêtre selon sain Ambrosie. Louvain: Imprimerie Orientaliste.

Jeronim (1845). De viris illustribus liber ad dextrum praetorio praefectum, adjuncta versione antiqua Graeca, quam sub Sophronii nomine Erasmus in lucem edidit. U: S. Eusebii Hieronymi Stridonensis presbyteri Opera omnia: Post monachorum Ordinis S. Benedicti e congergatione S. Mauri: Sed potissimum Joannis Martianaei [...]: Studio et labore Vallarsii et Maffaeii (str. 601-718). Vol. 2-3 (Patrologia latina, vol. 23). Parisi: Migne.

Jeronim (1908). Izabrane poslanice sv. Jeronima. Vol 1-2. Preveo I. Marković. Zagreb: Hrvatsko katoličko tiskovno društvo. (21990, Split: Književni krug.)

Jeronim (1996a). Epistulae: Pars I: Epistulae I-LXX. Uredio Isidorus Hilberg. Corpus scriptorum ecclesiasticorum latinorum (CSEL), vol. 54. Vindobonae: Österreichischen Akademie der Wissenschaften.

Jeronim (1996b). Epistulae: Pars II: Epistulae LXXI-CXX. Uredio Isidorus Hilberg. Corpus scriptorum ecclesiasticorum latinorum (CSEL), vol. 55. Vindobonae: Österreichischen Akademie der Wissenschaften.

Jeronim (1996c). Epistulae: Pars III: Epistulae CXXI-CLIV. Uredio Isidorus Hilberg. Corpus scriptorum ecclesiasticorum latinorum (SCEL), vol. 56/1. Vindobonae: Österreichischen Akademie der Wissenschaften.

Lécuyer, Joseph (1957). Le sacrement de l'épiscopat. Divinitas, 1, 221-251.

Leonardi, Giovanni (1977). Varietà di ministeri nelle comunità cristiane del primo secolo. U: Luigi Sartori (ur.), I ministeri ecclesiali oggi: Problemi e prospettive (str. 52-138). Roma: Borla.

Mišić, Anto (1990). Elementi svećeničke duhovnosti u pismima Sv. Jeronima. Obnovljeni život, 45(4), 219-232.

Pintard, Jacques; Daniélou, Jean (1960). Le saceroce selon saint Augustin: Le Prêtre dans la cité de Dieu. Paris: Mamme.

Schillebeeckx, Edward (21982). Il ministero nella Chiesa: Servizio di presidenza nella comunità di Gesù Cristo. Brescia: Queriniana.

Scipioni, Luigi I. (1977). Vescovo e popolo: L'esercizio dell'autorità nella chiesa primitiva (III secolo). Milano: Vita e Pensiero.

Stoico, Giuseppe (1972). L'Epistolario di S. Girolamo. Napoli: Giannini.

Tertulijan (1954). Opera II: Opera montanistica. Uredili Gerlo et al. Corpus Christianorum Series Latina (CCSL), vol. 2. Turnhout: Brepols.

Vanhoye, Albert (1980). Prêtres anciens, prêtre nouveau selon le Nouveau Testament. Paris: Seuil. 
On the Nature and Degree of Ordained Ministers in the Letters of St. Jerome Anto Mišić*

\section{Summary}

This article was written on the occasion of the 1600th anniversary of the death of St. Jerome, the great early Christian writer, Bible scholar and theologian. Jerome was born in Stridon, a small town on the border of Dalmatia and Pannonia which was destroyed by the Goths during his lifetime. The article presents Jerome's teaching on the nature and degree of ordained ministers based on a collection of 154 letters, 116 of which were written by Jerome and 16 of which were written to him. The collection contains also letters which Jerome translated into Latin, some of which are apochryphal. The importance and wealth of the letter collection is evident in the multiplicity and diversity of themes and in the considerable number of persons with whom Jerome corresponded. Jerome writes on ordained ministers in 27 of the 116 authentic letters, sometimes only implicating them, while he discusses the priesthood at greater length in four letters. Jerome uses terms applying to ordained ministers which were customary in his time, namely, bishop, presbyter and deacon. He very rarely uses the Latin terms sacerdos and sacerdotio, which apply exclusively to bishops and presbyters and not to deacons. When he wishes to unify all ordained ministers under one name, he uses the term clericus. In order for someone to become a minister of the Church, according to Jerome, the decisive factor is selection by and the mission of the community, while the laying on of hands is only a confirmation of the calling. In his letters Jerome speaks of the essence of the different degrees of ordained ministers (bishops and presbyters) and links them to the Apostles, the Sacraments and the Church. Their most important role in the community is the celebration of the Sacraments, particularly the Eucharist. Jerome's particularity lies in his resolute negation of an essential difference in the degree of Holy Orders between a bishop and a presbyter: he distinguishes them only through the ministry of each in the Church. Thus, the distinction is moreso sociological than ontological. Deacons are essentially different from bishops and presbyters as they are successors to the Seven chosen by the Apostles and designated to serve in the community. Although Jerome considers that there is no essential distinction within Holy Orders between a bishop and presbyter, he does not negate the difference in their role and the ministry they carry out in the Church. The roots of these differences are not theological, but rather societal and structural. Seeing as the Church is also a human community, She must have a structure similar to other human communities, such as the military or ship crew who are subservient to authority. letter

Key words: Church; bishop; presbyter; deacon; clergy; priest; ordained minister;

* Anto Mišić, Ph.D., Full Professor, Faculty of Philosophy and Religious Studies, University of Zagreb. Address: Jordanovac 110, 10000 Zagreb, Croatia. E-mail: amisic@ffrz.hr 